\title{
我与袁隆平先生的三次际遇
}

张启发

华中农业大学作物遗传改良国家重点实验室, 武汉 430070

E-mail: qifazh@mail.hzau.edu.cn

\section{My three encounters with Professor Yuan Longping}

\section{Qifa Zhang}

National Key Laboratory of Crop Genetic Improvement, Huazhong Agricultural University, Wuhan 430070, China E-mail: qifazh@mail.hzau.edu.cn

doi: 10.1360/TB-2021-0516

2021年5月22日, 我们景仰的袁隆平先生与世长辞. 半个 多世纪以来, 袁先生作为科学精神的一个标志性符号, 激励 着我们一代又一代的农业科学工作者攻坚克难, 勇往直前. 他的创新精神和他开创的事业, 为我们留下了丰富的遗产. 回想本人的科学生涯, 体认到我与袁先生有过三次重要际遇, 所受裨益终生难以忘怀. 特此追忆, 以资纪念.

第一次际遇发生在1987年, 我科学生涯的起点, 这次际 遇决定了我后来几十年的研究方向. 1986年, 我从美国留学 归来, 回到华中农业大学开始自己的科研工作. 在美国攻读 博士学位和做博士后工作期间, 我研究的是大麦群体遗传. 我很清楚, 回到国内, 尤其是回到湖北, 农业科研的主战场无 疑在水稻. 其时, 正值袁隆平先生领导的杂交水稻在中国取 得了巨大的成功, 国内对杂交水稻的育种、栽培和推广研究 可谓风起云涌. 但是我该如何起步呢? 正在我踌躇之际, 袁隆 平先生1987年在《杂交水稻》上发表了“杂交水稻的育种战 略设想”一文, 提出了杂交水稻育种的三个战略阶段: (1) 三系 法为主的品种间杂种优势利用，(2) 两系法为主的亚种间 (籼、粳)杂种优势利用, (3) 一系法远缘杂种优势的利用. 当 年启动的国家高技术研究发展计划(“863”计划)将“两系法亚 种间杂交稻的培育”作为农业生物技术领域的主要攻坚目标 之一, 列人了“ 101 ”主题. 袁先生的文章和“ 863 ”计划提出的目 标对我确定研究方向产生了重要影响.

“两系法”杂交稻培育的一个关键元素是光温敏雄性不 育系. 1973年, 湖北泟阳的石明松先生在沙湖原种场种植的 晚粳稻“农旺58”中发现了一个雄性不育突变(我们称为 “58S”), 其后 10 多年的研究确定该不育株的育性受光周期调 控, 在长日条件下表现出雄性不育, 在短日条件下正常可育. 20 世纪 80 年代中期, 很多单位都在利用光敏不育水稻培育新 的杂交稻, 1987年启动的国家“863”计划将光敏不育基因的克

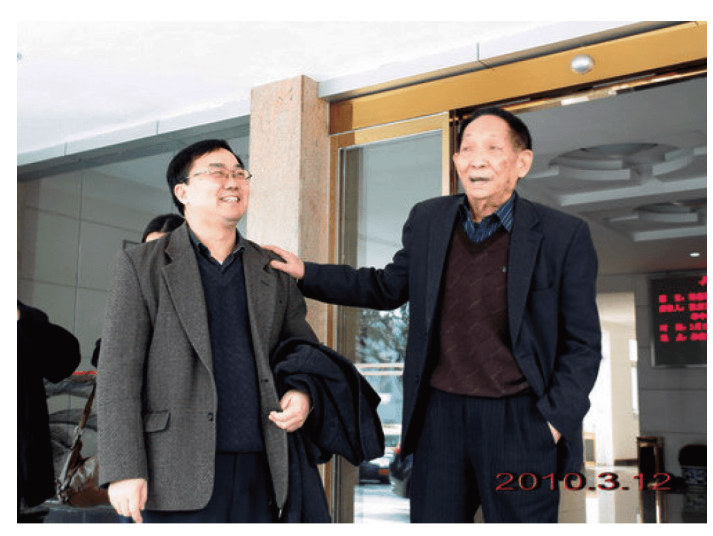

张启发(左)与袁隆平(右)

隆作为内容之一, 随后国家自然科学基金委员会还设立了光 敏不育水稻研究的重大项目, 一时间, 似乎全国的水稻科研 人员都在开展光敏不育水稻的研究工作. 1987 年, 我在农业 部(现农业农村部)的生物技术计划中申请到一个课题, 经费 8 万元, 要在 3 年内克隆光敏不育基因. 由此开始了我的水稻科 研生涯. 我们课题组经过10多年的艰苦工作, 到1999年, 获得 了如下成果: $58 \mathrm{~S}$ 为农旺 58 的单基因突变, 该基因 $(P m s 3)$ 位于 水稻第 12 染色体, 而 $58 \mathrm{~S}$ 与多数品种还有另外一个基因 $(P m s 1)$ 的差异, 位于第7染色体. 2012年, 我们发表了 $P m s 3$ 克 隆的论文, 该基因为一个长链非编码RNA. 2016年, 我们发表 了 Pms l 基因的克隆文章, 有趣的是该基因也编码长链非编码 RNA, 而且是被剪切成为若干长度为 $21 \mathrm{nt}$ 的小RNA来调控育 性. 一个 3 年的课题, 一做就是 30 年. 目前我们还在继续对这 些小片段RNA的调控机理进行研究.

“亚种间”杂交稻的一个关键元素是广亲和基因. 籼稻与 
粳稻杂交, 杂种育性一般较差, 结实率低. 这个现象生物学上 叫作“生殖隔离”, 是物种形成和得以维系的基本机制. 袁隆平 先生的文中提出用广亲和基因来克服杂种育性低的问题. 1986年, 日本学者池桥宏报道, 某些水稻品种第6染色体有一 个广亲和基因 $S 5$, 带 $S 5$ 基因的品种(广亲和品种)无论是与籼 稻还是粳稻杂交, 其杂种均能正常的结实. 于是, 本课题组于 1991年开始广亲和基因的研究，2012年我们发表了该基因克 隆的结果, 揭示出 $S 5$ 位点由三个紧密连锁的基因构成, 编号 3、4、5, 构成一个“杀手-护卫”工作模式. 在籼稻中，3号和 5 号基因有功能(3+, 5+), 4号基因没有功能(4-); 粳稻则相反, 4 号基因有功能(4+), 3 号、5号没有功能(3-, 5-). 有功能的5号 与4号基因一起(4+, 5+), 构成杀手, 而3号基因(3+)则行使护 卫作用. 在雌配子形成过程中, 4 号和 5 号基因 $(4+, 5+)$ 共同作 用杀死配子，籼型配子由于 $3+$ 的保护，正常存活，粳型配子 (3-)无3+的保护而死亡. 其结果, 籼粳杂种表现为半不育. 广 亲和品种没有杀配子的功能, 故与籼、粳稻均能产生正常可 育杂种. 这一研究结果极大地促进了亚种间杂交稻的培育, 同时也丰富了演化遗传学中生殖隔离的理论.

高水平杂交稻的培育依赖对杂种优势的生物学机制认 识. 然而, 由于实验材料、研究思路及研究的技术手段诸多 方面的限制，世界上关于植物杂种优势形成机制的研究在过 去近百年进展不大. 1981年, 福建三明农业科学研究所谢华 安先生培育出杂交稻品种“汕优63”，由于其优势强，适应性 广, 到1989年年种植面积超过 1 亿亩, 成为有史以来在我国年 种植面积最大的水稻品种. 本课题组于1991年以汕优63为材 料开始了杂种优势的生物学基础的研究. 通过“永久F2”群体 设计，应用新兴的基因组技术，解析了加性、显性、上位性 等杂种优势的遗传组分, 克隆了决定产量和杂种优势的基因 如GS3、Ghd7、Ghd7.1等，为进一步提高杂种优势利用水平 提供了理论基础和基因资源.

上述研究成果, 使我和袁隆平、李家洋先生一起获得了 2018年的未来科学大奖生命科学奖.

第二次际遇发生在 2010 年, 这次际遇在困境中给我以鼓 舞和力量. 2009年, 我们课题组研发的转基因抗虫水稻“Bt 恢63”及其杂种“Bt汕优63”在经过了 10 年的生产性实验和安 全性评估之后通过了国家转基因生物安全委员会的评价，农 业部(现农业农村部)有关负责人于同年11月到华中农业大学 向学校颁发了该转基因水稻的两张安全证书. 安全证书的颁 发, 水稻科学界欢欣鼓舞, 认为转基因水稻商业化生产的时 机已经到来, 我国农业生物技术产业化将迎来一个新的局面. 然而, 受某些势力的操控, 社会與论对转基因水稻的攻击抹 黑也到了白热化的程度, 本人深陷转基因水稻與论围攻和谩 骂的困境之中, 不堪其苦.

值此困难之际, 2010 年3月 12 日, 袁隆平先生邀请我到长 沙, 共话转基因水稻. 时年, 袁先生已年届八旬, 仍精神賏铄. 报告之前, 他在办公室热情地接待了我, 然后安排我在他们
杂交水稻工程技术中心报告厅作了题为“转基因作物的机遇 和挑战”的报告, 袁先生亲自主持了报告会. 参加报告会的有 国家杂交稻工程技术研究中心、中国科学院亚热带农业生 态研究所、湖南省农业科学院、湖南农业大学等单位的研 究人员，以及参加“2010年超级杂交稻第三期目标攻关会议” 的湖南省基层农技干部共 200 余人.

袁先生兴致勃勃地听完了报告. 在报告提问的环节，袁 先生就转基因抗虫水稻的安全性实验、抗除草剂转基因作 物除草剂用量等问题行了讨论, 并表示了对转基因作物的研 发和政府的决策热情支持的态度. 他说，转基因作物的发展 是全球趋势，转基因技术的运用肯定是今后发展的方向，将 常规育种技术与分子技术相结合将会使我们水稻的育种工 作如虎添翼. 为了消除公众对转基因抗虫稻米安全性顾虑的 问题，他表示愿意作为第一个志愿者来吃，并热情地号召现 场的观众都来吃. 报告会听众提问踊跃, 讨论气氛活跃, 整个 报告会历时近3小时.

报告会后, 袁先生还组织国家杂交稻工程技术研究中心 研究人员与我们一行进行了座谈交流. 我们双方均期待充分 利用各自在水稻基础研究和育种实践中的互补优势，在信息 共享、人才培养、项目研究等方面进一步加强沟通与合作, 共同努力更好地推动我国水稻科研事业的发展，为确保我国 粮食安全作出新贡献.

报告会活动结束后我与他辞别, 袁先生深情地拍着我的 肩膀, 鼓励我要克服困难, 顶着压力坚持下去. 这次长沙之行 给了我很大的鼓励.

第三次际遇发生在 2018 年，这次际遇鼓励我再接再厉， 终生奋斗. 这一年, 我与李家洋、袁隆平先生共享未来科学 大奖生命科学奖. 我自己的感觉是, 与袁先生对粮食生产的 贡献相比, 本人在杂种优势相关方面的研究成果比较渺小, 这次获奖颇感意外. 袁先生因为身体的原因, 没有参加在北 京举行的颁奖典礼，用视屏发表了获奖感言. 虽然88岁的高 龄, 但老骥伏枥、志在千里的豪情壮志依然洋溢, 他说道: “我还有两个梦, 一个是禾下乘凉梦, 一个是杂交水稻覆盖全 球梦. 我的心愿是发展杂交水稻, 造福世界人民. 我衷心期望, 杂交水稻这一成果不但能够增强我们饭碗牢牢地掌握在中 国人的手里的能力, 同时也为保障世界粮食安全发挥重要的 作用.”在中华文化中, 88 是“米”字, 在米寿之年获此大奖, 对 水稻人是非常吉利的事情. 听着他的讲话，除了佩服他的精 神外, 还期待上苍再赐 20 年, 让袁先生能实现他的宏愿.

与袁先生相似, 我也有两个梦, 也一直在为之奋斗.一个 是“绿色超级稻”梦, 让水稻生产“少打农药、少施化肥、节水 抗旱、优质高产”，让粮食安全和资源与环境均能可持续发 展, 让农业绿色. 一个是绿色营养优质稻米梦, 通过黑米主食 化, 保障粮食安全, 促进营养健康. 我们要学习袁隆平先生坚 定执着的“追梦”精神，带领团队为实现这些目标更加积极努 力地工作, 生命不息, 奋斗不止. 